\title{
PARTISIPASI PEREMPUAN DALAM PENDIDIKAN TINGGI DAN PENGARUH PENDIDIKAN TINGGI PADA PEREMPUAN: SEBUAH STUDI LITERATUR
}

\author{
FANNI ERDA TASIA ${ }^{1)}$, ENOK NURHASANAH ${ }^{2)}$ \\ ${ }^{1}$ Dosen Program Studi Pendidikan Ekonomi Universitas Pamulang \\ ${ }^{2}$ Dosen Program Studi Pendidikan Ekonomi Universitas Pamulang \\ ${ }^{*}$ email: $\underline{\text { dosen02237@unpam.ac.id }}{ }_{2}^{1} \underline{\text { dosen02222@unpam.ac.id }}^{2}$
}

\begin{abstract}
ABSTRAK
Penelitian ini mengkaji bagaimana tingkat partisipasi perempuan dalam Pendidikan tinggi serta apa pengaruh dari pendidikan tinggi tersebut terhadap perempuan. Metode yang digunakan dalam penelitian ini adalah Studi Literatur terhadap 15 Jurnal yang menganalisis mengenai Pendidikan pada Perempuan, Tingkat Partisipasi dan Pengaruh Pendidikan tersebut pada Perempuan. Hasil penelitian menunjukkan bahwa partisipasi perempuan dalam pendidikan tinggi berbeda-beda pada setiap negara. Peningkatan partisipasi dalam pendidikan tinggi pada suatu negara terjadi karena meningkatnya kesadaran perempuan akan pentingnya pendidikan untuk perbaikan kualitas diri dan kehidupannya. Sedangkan negara yang tingkat partisipasi perempuan dalam pendidikan tingginya masih rendah, penyebab utamanya adalah aspek sosial budaya yang masih diyakini oleh masyarakatnya bahwa pendidikan bukanlah suatu hal vital untuk dimiliki oleh perempuan. Selanjutnya, pendidikan tinggi pada perempuan memberikan pengaruh positif bagi diri perempuan itu sendiri maupun bagi lingkungan sekitarnya. Peningkatan Pengetahuan, Keterampilan dan Keahlian merupakan komponen dasar yang didapatkan oleh perempuan dengan pendidikan tinggi sehingga hal tersebut membawa mereka pada kualitas kehidupan yang lebih baik dan mampu membawa perubahan sosial maupun ekonomi untuk lingkungan keluarga, masyarakat dan bangsa.
\end{abstract}

Kata Kunci: Perempuan dan Pendidikan Tinggi 


\section{PENDAHULUAN}

Pendidikan adalah sebuah keharusan. Sreenivasulu (2013, hlm. 32) menjelaskan bahwa pendidikan merupakan sesuatu yang penting untuk membangun pengetahuan dan keterampilan intelektual bagi manusia. Bhardwaj (2014, hlm. 24) juga turut mendefinisikan pendidikan sebagai "'essencial of human virtue", yang bermakna bahwa Pendidikan merupakan kebijakan manusia yang paling esensial dan dasar untuk berkehidupan yang baik dimasa depan.

Dewasa ini, pendidikan bukanlah sesuatu yang eksklusif sehingga hanya orang-orang tertentu saja yang dapat mengaksesnya, namun lebih dari itu merupakan sebuah keniscayaan bagi setiap manusia, tak terkecuali bagi perempuan. Memiliki Pendidikan yang tinggi sudah menjadi perhatian penting untuk perempuan masa kini sebagaimana pernyataan Margaret (2017, hlm. 1) bahwa Education for women has been a priority. Pentingnya perempuan memiliki pendidikan tinggi karena Pendidikan merupakan salah satu jalan yang akan membawa perempuan melewati derasnya arus globalisasi seperti yang disampaikan Nurkholis (2013, hlm. 24) bahwa Education can prepare human to face the globalization.

Namun, belum semua perempuan menyadari arti penting Pendidikan padahal Pendidikan juga merupakan sebuah investasi untuk membentuk sumberdaya manusia yang berkualitas (Balatchandirane, 2007, hlm. 6). Salah satu contoh masih rendahnya kesadaran perempuan untuk memperoleh Pendidikan tinggi terjadi di Uganda. Jumlah perempuan yang tidak menyelesaikan pendidikannya atau dropout adalah sebesar $40,7 \%$ (Datzberger and Marielle 2018, hlm. 65). Berikutnya, permasalahan mengenai rendahnya kesadaran perempuan atas Pendidikan juga terjadi Di Afghanistan. Hanya 19\% jumlah perempuan dari seluruh total mahasiswa yang mengakses pendidikan tinggi pada tingkat sarjana (Morley and Barbara, 2015, hlm. 22).

Berdasarkan kepada latar belakang permasalahan tersebut, 
disinyalir masih terdapat kurangnya kesadaran perempuan terhadap pentingnya Pendidikan. Sehingga penelitian ini mengkaji mengenai tingkat partisipasi perempuan dalam Pendidikan tinggi dan bagaimana pengaruh Pendidikan tinggi pada perempuan. Adapun Pendidikan tinggi yang dimaksud dalam penelitian ini adalah Pendidikan pada jenjang Universitas.

\section{METODE PENELITIAN}

Penelitian ini menggunakan metode penelitian Studi Literatur. Arikunto (2006) menjelaskan bahwa Studi Literatur merupakan sebuah metode pengumpulan data melalui pencarian informasi menggunakan buku maupun literatur-literatur yang lain sehingga terbentuklah landasanlandasan teori. Literatur dalam penelitian ini berasal dari 15 Jurnal yang terkait dengan pendidikan untuk perempuan. Kajian atas literatur ini dijadikan sebagai landasan dasar dalam menganalisis Bagaimana Partisipasi Perempuan Dalam Pendidikan Tinggi Dan Pengaruh Pendidikan Tinggi Pada Perempuan.

\section{HASIL PENELITIAN}

\section{Partisipasi Perempuan dalam Pendidikan}

Perhatian mengenai keadaan pendidikan perempuan salah satunya termaktub dalam program Millennium Development Goals (MDGs) dimana pada MDGs 2 fokus mengkaji mengenai kesetaraan gender dalam dunia pendidikan dan pada MDGs 3 menitikberatkan kepada pemberdayaan perempuan. Kesetaraan gender menyangkut akses terhadap laki-laki dan perempuan dalam pendidikan juga telah dideklarasikan dalam Universal Declaration of Human Rights dan The Jominten and Beijing Declarations (Aikman and Elaine, 2005, hlm. 15 dan 27). Hal ini menunjukkan bahwa terdapat keseriusan dari berbagai pihak untuk meningkatkan akses perempuan terhadap dunia pendidikan agar mendapatkan hak dan kesempatan yang sama dengan laki-laki dalam mengakses pendidikan.

Beragam penelitian juga dilakukan untuk mengkaji bagaimana kondisi Pendidikan perempuan. Gali, Halah dan Margalit (2015, hlm. 9) 
menemukan bahwa Perempuan Arab dan Israel sudah menyadari arti penting pendidikan sehingga jumlah perempuan dengan pendidikan tinggi semakin meningkat. Mereka menyadari bahwa pentingnya pendidikan tinggi untuk meningkatkan mobilitas sosial dan status ekonomi. Namun, dengan memiliki pendidikan tinggi tidak serta merta memberikan kemudahan bagi mereka dalam mengakses dunia pekerjaan. Hal ini karena pengaruh budaya dalam peran gender masih kuat.

Berikutnya temuan yang berseberangan berasal dari Jain et al, (2017, hlm. 1). Di India, terdapat beragam alasan mengapa anak perempuan tidak mendapatkan akses kesehatan bahkan akses pendidikan seperti yang didapatkan oleh lakilaki. Diantara alasan tersebut adalah budaya, dimana dalam budaya india seorang anak perempuan dinilai sebagai sebuah 'beban" dibandingkan dengan anak laki-laki yang dinilai sebagai sebuah 'berkah'. Perbedaan persepsi yang pada akhirnya sudah menjadi budaya secara turun temurun inilah yang menyebabkan rendahnya tingkat pendidikan tinggi untuk perempuan India dibandingkan laki-laki.

Mukitul dan Niaz (2018, hlm. 1) menyebutkan bahwa akses perempuan dalam pendidikan masih tergolong lebih rendah dibandingkan laki-laki sehingga pekerjaan perempuan pun sebagian besar kurang bergengsi dan banyak bergelut dengan kegiatan-kegiatan domestik rumah tangga. Di Afghanistan, hanya 19\% jumlah perempuan dari total mahasiswa yang mengakses pendidikan tinggi pada tingkat Universitas sedangkan di Nepal, persoalan gender dalam pendidikan juga terjadi antara perempuan yang berasal dari kasta rendah dan kasta yang lebih tinggi (Morley and Barbara, 2015, hlm. 22 dan 40).

Qudsia, Syeda dan Imrab (2013, hlm. 15) menemukan bahwa di Pakistan, terdapat ketidaksetaraan antara laki-laki dan perempuan dalam hal kemampuan mengakses pendidikan tinggi di universitas hingga kemampuan perempuan dalam mengakses pekerjaan dan jabatan yang tinggi. Angka literasi 
untuk perempuan masih rendah hanya berada pada angka $24 \%$ dan laki-laki sudah berada di angka $49 \%$ sedangkan $60 \%$ penduduk yang buta huruf adalah perempuan. Faktor agama, sosial budaya dan norma yang berlaku dimasyarakat menjadi penyebab ketidaksetaraan hak-hak yang dimiliki oleh perempuan dalam mengakses kesehatan, pendidikan dan pekerjaan.

Selanjutnya di Indonesia, Priyatna (2013, hlm. 5) Mengemukakan berdasarkan data sensus penduduk Tahun 2010, diketahui hanya sebesar $6,62 \%$ perempuan yang berhasil memperoleh gelar sarjana. Namun pergeseran fenomena partisipasi perempuan dalam pendidikan tinggi terjadi pada tahun 2018, dimana menurut data BPS, jumlah perempuan yang berhasil mencapai pendidikan tinggi di perkotaan berada pada angka 10,79\%. Berikut adalah data BPS mengenai jumlah perempuan yang memiliki Pendidikan tinggi dari tahun 2016, 2017 dan 2018.

Tabel 1. Penduduk di Perkotaan Berumur 10 Tahun ke atas Menurut
Jenis Kelamin dan Ijazah Tertinggi Yang Dimiliki (Akademi/D III/ D $\mathrm{IV} / \mathrm{S} 1 / \mathrm{S} 2 / \mathrm{S} 3$ )

\begin{tabular}{ccc}
\hline Tahun & Laki-Laki & Perempuan \\
\hline 2016 & 9,63 & 9,71 \\
\hline 2017 & 10,25 & 10,23 \\
\hline 2018 & 10,41 & 10,79
\end{tabular}

Sumber: Data BPS Tahun 2018

Data di atas menunjukkan bahwa dari tahun 2016 hingga tahun 2018 terjadi peningkatan partisipasi perempuan terhadap pendidikan tinggi, bahkan persentase perempuan pada tahun 2016 dan Tahun 2018 lebih tinggi dibandingkan laki-laki dalam mengakses pendidikan tinggi.

Berdasarkan kepada beberapa kajian literatur terhadap tingkat partisipasi perempuan dalam pendidikan tinggi di beberapa negara, maka terdapat perbedaan tingkat partisipasi perempuan dalam pendidikan tinggi. Pada negara yang mana tingkat partisipasi perempuan terhadap pendidikan tinggi sudah meningkat, dapat diidentifikasi faktor-faktor penyebabnya diantaranya adalah meningkatknya kesadaran perempuan akan pendidikan yang mampu memberikan dampak positif pada 
peningkatan kualitas diri pribadi, status sosial dan status ekonomi (Gali, Halah dan Margalit 2015, hlm. 9).

Sedangkan pada negara yang tingkat partisipasi perempuan terhadap Pendidikan tinggi masih tergolong rendah, maka beberapa faktor penyebabnya adalah faktor budaya (Jain et al, 2017, hlm. 1) dimana menurut nilai-nilai budaya yang dianut, memiliki pendidikan hingga ke jenjang yang tinggi bukanlah sebuah prioritas untuk perempuan, sehingga tidak adanya dukungan atau Support yang kuat dari keluarga dan lingkungan untuk untuk perempuan mengejar pendidikan hingga jenjang tertinggi (Samela 2006, hlm. 63).

\section{Pengaruh Pendidikan Tinggi}

\section{Pada Perempuan}

Salah satu tokoh india menyebutkan bahwa "when we educate a man, we just educate an individual, but if we educate a woman it's mean we educate a whole family" (Shetty, 2015 hlm. 1). Pernyataan tersebut mengindikasikan bahwa betapa besarnya dampak pendidikan untuk perempuan.
Sebagai guru pertama untuk anakanaknya, perempuan yang terdidik berarti akan mampu menciptakan generasi terdidik dalam keluarganya. Anak-anak yang cerdas dan sukses dimasa depan sangat tergantung kepada bagaimana treatment seorang ibu untuk memberikan Pendidikan pertama kepada anak-anaknya.

Dewasa ini, meskipun pada beberapa negara sudah terdapat kemajuan mengenai akses perempuan dalam pendidikan tinggi, namun masih terdapat negara-negara yang jumlah perempuan mengenyam pendidikan tingginya masih rendah. Rendahnya akses perempuan terhadap pendidikan tinggi ini tentunya akan menimbulkan beberapa persoalan baik untuk diri perempuan itu sendiri maupun untuk lingkungannya. Saxesana (2017, hlm. 1) menyebutkan bahwa Pendidikan merupakan cara terbaik untuk pemberdayaan perempuan. Perempuan berpendidikan akan lebih mampu bertahan menghadapi kesulitan, memiliki sikap mental yang jauh lebih baik dalam memecahkan persoalan-persoalan yang ditemui dalam kehidupan. 
Somani (2017, hlm. 132) menjelaskan bahwa Pendidikan dapat meningkatkan kapabilitas seseorang, begitupun perempuan. Pendidikan penting untuk perempuan bukan karena alasan bahwa jenis kelamin mereka adalah perempuan sehingga harus memperoleh pendidikan, tetapi karena mereka adalah manusia yang memang berhak untuk mendapatkan pendidikan yang setara karena pendidikan juga merupakan hak dasar bagi setiap manusia baik laki- keterampilan untuk memahami persoalan kehidupan secara mendalam dan menjadi cerdas secara kognitif maupun emosional dalam menyikapi berbagai tantangan kehidupan.

Somani (2017, hlm. 130) menggambarkan hasil analisisnya mengenai alasan mengapa pendidikan merupakan hal penting untuk perempuan. Adapun gambaran hasil analisis tersebut dapat dilihat di bawah ini.

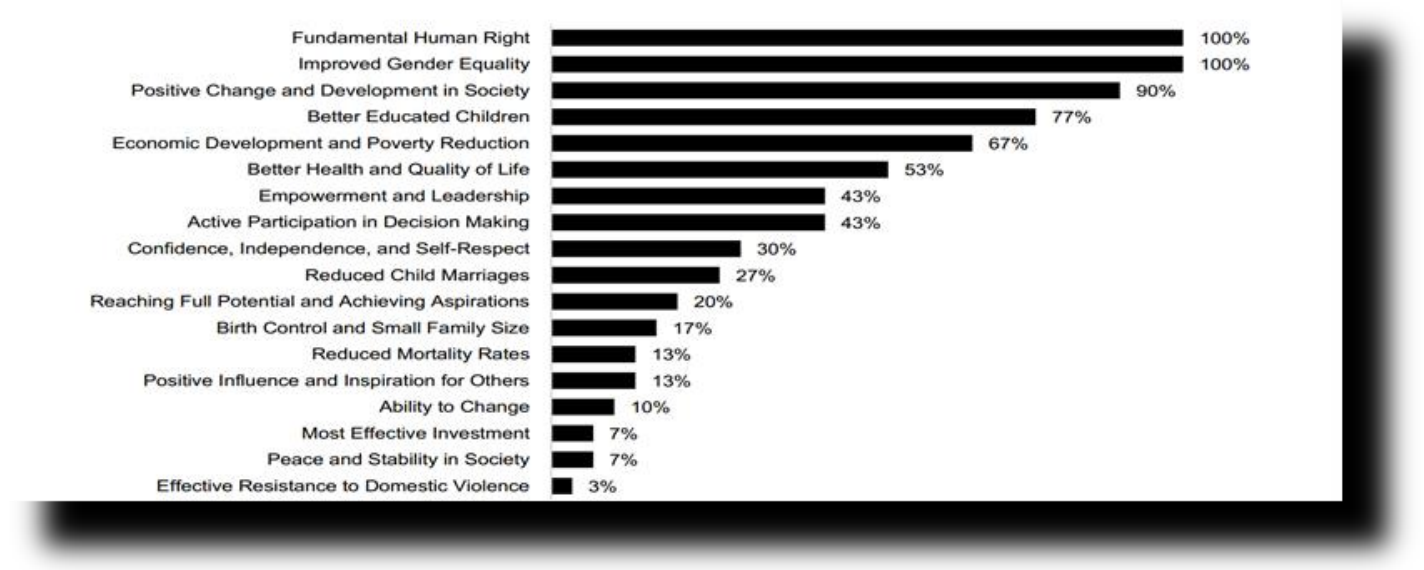

Gambar 1. Alasan Pentingnya Pendidikan Untuk Perempuan Sumber: Somani 2017, hlm. 130.

laki maupun perempuan. Pemberian pendidikan yang layak bagi perempuan tentunya mendatangkan dampak positif bagi mereka dan juga bagi keseluruhan kehidupan keluarganya karena perempuan terdidik memiliki pengetahuan dan
Merujuk kepada gambar tersebut, dapat dipahami bahwa alas an utama mengapa Pendidikan sangat penting untuk perempuan adalah karena memang sudah menjadi hak dasar setiap manusia 
untuk memperoleh Pendidikan yang layak, begitupun untuk perempuan.

Margaret (2017, hlm. 2) megidentifikasi pengaruh Pendidikan tinggi pada perempuan yang terdiri dari beberapa poin berikut ini:

1. Pendidikan mampu memberdayakan perempuan secara utuh. Pemberdayaan perempuan ini akan meningkatkan kecerdasan, sikap maupun keterampilan sehingga akumulasi dari dampak positif Pendidikan secara luas akan mampu meningkatkan kontribusi perempuan dalam pembangunan dan kesejahteraan kehidupan suatu bangsa.

2. Pendidikan tinggi pada perempuan secara mikro akan mampu meningkatkan perekonomian keluarga dan secara makro akan mampu meningkatkan perekonomian negara.

3. Peningkatan kualitas kehidupan. Perempuan dengan pendidikan tinggi akan memiliki kualitas kehidupan yang jauh lebih baik dibandingkan dengan perempuan yang tidak memiliki pendidikan tinggi. Mereka tidak akan kehilangan identitasnya secara individu serta memahami dengan baik apa hak-hak yang mereka miliki sehingga tidak dapat diinjak-injak oleh orang lain.

4. Peningkatan kesehatan. Perempuan yang memiliki Pendidikan tinggi juga memiliki kesadaran yang tinggi akan kesehatan. Gaya hidup sehat yang kemudian diterapkan oleh para perempuan dalam lingkungan keleuarganya akan menghasilkan generasi yang juga sehat.

5. Keadilan. Pendidikan tinggi memberikan pemahaman yang baik pada perempuan mengenai perlakuan yang adil yang harus mereka terima dilingkungan bermasyarakat, sehingga akan dapat mengurangi kasus-kasus seperti tindak kekerasan pada perempuan.

6. Prasyarat untuk memasuki dunia pekerjaan dengan beragam profesi adalah Pendidikan. Sehingga perempuan terdidik akan memiliki kesempatan yang luas untuk memilih profesi apa yang akan dia jalankan dikehidupannya. 
7. Pemberian pendidikan tinggi pada perempuan juga mampu mengurangi tingkat kemiskinan. Hal ini karena semakin tinggi jumlah perempuan terdidik, akan semakin meningkat kualitas kehidupannya karena memiliki kemampuan untuk mengakses pekerjaan yang baik sehingga akan mampu mengurangi tingkat kemiskinan.

Cannonier and Naci (2018, hlm 3) menyebutkan bahwa peningkatan pendidikan pada perempuan meningkatkan kesadaran mereka akan hal-hal yang tidak baik untuk dirinya sendiri, sehingga membantu perbaikan kesehatan dan kesejahteraan bagi perempuan. Ahmad (2015, hlm. 190) menjelaskan bahwa pendidikan pada perempuan merupakan sebuah Tool atau alat yang dapat merubah sebuah masyarakat. Memberikan pendidikan pada perempuan berarti memberikan perbaikan pada berbagai aspek kehidupan seperti mentalitas, sikap dan cara pandang perempuan dalam kehidupan. Perempuan terdidik juga akan mampu mendidik anak-anaknya dengan lebih baik sehingga dari tangan-tangan merekalah generasi cerdas dibentuk.

Berangkat dari penjelasan yang telah dipaparkan mengenai bagaimana pengaruh pendidikan tinggi pada perempuan, dapat dijelaskan bahwa pendidikan tinggi secara garis besar akan memberikan dua dampak, pertama dampak internal untuk perempuan itu sendiri, kedua dampak eksternal dari perempuan terhadap lingkungan diluar dirinya. Dampak internal atas pendidikan tinggi yang dimiliki perempuan adalah peningkatan kualitas dirinya sebagai Human Being. Perempuan terdidik memiliki nilai tambah sebagai seorang manusia yaitu berupa "kecerdasan" yang dia miliki, bukan hanya secara intelektual, tapi kecerdasan secara emosional dan sikap dalam mengahadapi tantangan kehidupan.

Sedangkan pengaruh Pendidikan tinggi secara eksternal adalah kemampuan perempuan untuk berkontribusi positif bagi perbaikan kualitas kehidupan masyarakat karena mereka akan melahirkan generas-generasi yang cemerlang, serta mereka mampu meningkatkan 
produktifitas suatu negara karena dengan Pendidikan mereka juga memberikan kontribusi dalam dunia pekerjaan sehingga peningkatan perekonomian dan pengurangan angka kemiskinan dan pengangguran dapat tercapai.

\section{KESIMPULAN}

$\begin{array}{rrr}\text { Studi } & \text { literatur } & \text { mengenai } \\ \text { partisipasi } & \text { perempuan } & \text { dalam }\end{array}$ Pendidikan tinggi dan pengaruh pendidikan tinggi bagi perempuan menghasilkan pemahaman bahwa tingkat partisipasi perempuan atas Pendidikan tinggi berada pada level yang berbeda di masing-masing negara. Dari beberapa literatur yang telah dianalisis, peningkatan partisipasi perempuan dalam Pendidikan tinggi disebabkan karena adanya peningkatan Awarness atau kesadaran perempuan akan pentingnya manifestasi Pendidikan untuk kehidupannya. Sedangkan pada negara yang tingkat partisipasi perempuan dalam Pendidikan tingginya masih tergolong rendah dibandingkan laki-laki, salah satu penyebab umumnya adalah factor social dan budaya. Filosofi lama yang masih mempengaruhi cara pandang perempuan bahwa Pendidikan bukanlah hal vital untuk mereka, pada akhirnya masih memberikan sumbangan besar bagi rendahnya tingkat Pendidikan tinggi pada perempuan.

Adapun pengaruh Pendidikan tinggi pada perempuan dalam lingkup yang kecil adalah peningkatan kualitas dirinya sebagai manusia baik dari segi kecerdasan, sikap, kapabilitas maupun keahlian yang dimilikinya. Secara lebih luas, Pendidikan tinggi pada perempuan akan berkontribusi untuk memberikan peningkatan kualitas kehidupan dalam suatu bangsa.

\section{DAFTAR PUSTAKA}

Ahmad, Rouf. Bhat. 2015. Role of Education in the Empowerment of Women in India. Journal of Education and Practice. 6 (10).

Aikaman, Sheila and Elaine Unterhalter. 2005. Beyond Accsess: Transforming Policy and Practice for Gender Equality and Education. United Kingdom: Oxam GB.

Arikunto, S. 2006. Metode Penelitian Kualitatif. Jakarta: Bumi Aksara. 
Balatchandirane, G. 2007. Gender Discrimination in Education and Economic Development: A Study of Asia. Japan: Institute of Developing Economies.

Berita Resmi Statistik. 2018. Keadaan Ketenagakerjaan Indonesia Februari 2018. Jakarta: Badan Pusat Statistik.

Bhardwaj, Ajay. 2016. Importance of Education in Human Life. A Holistic Approach. International Journal of Science and Consciousness. 2 (2).

Cannonier, Colin And Naci Mocan. 2018. The Impact of Education on Women's Preferences for Gender Equality: Evidence from Sierra Leone. Journal of Demographic Economics. 84 (3).

Datzberger, Simone and Marielle Le Mat. 2018. Just Add Women and Stir? Education, Gender and Peacebuilding in Uganda. International Journal of Educational Development. 69 (1).

Gali, Rachel Cinamon, Halay Habayid and Margalit Ziv. 2015. The Conception of Work and Higher Education Among Israeli and Arab Women. International Journal of Educational Research. 4 (4).
Jain et al. 2017, Women Education in Rural India. International Journal of Social Sciences and Humanities. 1 (7).

Margaret, Prameela. 2017. Woman Education in India. International Journal of Development Research. 7 (12).

Morley Louise and Barbara Crossouard. 2015. Women in Higher Education Leadership in South Asia: Rejaction, Refusal, Reluctance, Revisioning. Inggris: University of Sussex.

Mukitul, Kazi Islam Dan Niaz Asadullah. 2018. Gender Stereotypes and Education: A Comparative Content Analysis of Malaysian, Indonesian, Pakistani and Bangladeshi School Textbooks. Research Article.

Nasir, Lilianti. 2017. Persamaan Hak :Partisipasi Wanita dalam Pendidikan. Jurnal Pendidikan dan Ilmu Pengetahuan. 17 (1).

Nurkhilos. 2013. Pendidikan Dalam Upaya Memajukan Teknologi. Jurnal Kependidikan. 1 (1).

Priyatna, Aquaini. 2013. Negotiating and Rethinking Local Culture: The Narratives of Indonesian Women Juggling Higher Education, Work, and Domestic Roles. Asian Journal of Women's Studies. 19 (4). 
Qudsia, Syeda Batool, Sajid and Imrab Shaheen. 2013. Gender and Higher Education in Pakistan. International Journal of Gender and Woman's Studies. 1(1).

Sameela, tefaye. 2006. Higher Education Expansion and The Gender Question in Ethiopia: A Case Study of Women in a Public University. The Ethiopian Journal of Higher Education. 3 (1).

Saxena, Kalpana. 2017. Status of Women Education in India with Particular Reference to Women Empowerment and Development. IOSR Journal Of Humanities And Social Science. 22 (3).

Screenivasulu, Sri. 2013. Role and Importance Educational for Effective Growth of Indian Economy: An Overview. IOSR Journal of Humanities and Social Science. 7 (5).

Shetty, S. Sowjanya. 2015. Role of Education in Women Empowerment and Development: Issues and Impact. National Seminar On Education.

Somani, Tabreek. 2017. Importance of Educating Girls for the Overall Development of Society: A Global Perspective. Journal of Educational Research and Practice. 7 (1) 